\title{
Vertical profiles of arsenic and arsenic species transformations in deep-sea sediment, Nankai Trough, offshore Japan
}

\author{
Harue Masuda ${ }^{1 *}$ DD, Haruka Yoshinishi ${ }^{1}$, Shigeshi Fuchida ${ }^{1,2}$, Tomohiro Toki $^{3}$ and Emilie Even ${ }^{1}$
}

\begin{abstract}
Concentrations of arsenic (As) and its chemical forms were determined on deep-sea sediments drilled at three sites of Nankai Trough, off the Kii Peninsula, Japan. Those sediments were analyzed to document the behavior of As in relation to methane hydrate formation and the deep biosphere.

The analytical results showed the total As concentration of interstitial water (IW) and squeezed cake (SC) ranged from 0.9 to $380 \mathrm{ppb}$ and from 3 to $14 \mathrm{ppm}$ (average, $6.4 \mathrm{ppm}$ ), respectively. The sediments from Site C0002, of which sediment column was the longest down to $2200 \mathrm{~m}$ below the seafloor (mbsf) among the studied three drilling sites, were analyzed for the host phase transformation of As. The total concentration of As of IW and SC from 200 to 500 mbsf, where methane hydrate zone was included, was higher than those from the uppermost 200 $\mathrm{m}$. Concentration of As was ultimately controlled by pH. Also, organoarsenicals, such as methylarsonic acid (MMA) and arsenobetaine (AsB), were detected in the sediment column, implying that these organoarsenicals appeared in relation to the in situ microbial activities. These observations suggest that As becomes mobilized directly or indirectly as a result of microbial activity in deep-sea sediments.
\end{abstract}

Keywords: Nankai Trough, Deep biosphere, Organoarsenical, Convergent margin

\section{Introduction}

Distribution and behavior of arsenic (As), one of the most common toxic elements, in the hydrosphere and subareal and under-water shallow sediments have been well documented as a part of geologic cycle of arsenic in the Earth's surface and crust (e.g., Masuda 2018, and references therein). The As is generally present in clean, open-ocean water at an average concentration of $1.5 \mu \mathrm{g} / \mathrm{L}$ (e.g., Andreae 1979). Marine organisms, particularly photosynthetic organisms, take up As from seawater and accumulate it in their bodies, where metabolic reactions result in As species transformations. Biogeochemical processes affecting As in ocean water have been well documented (e.g., Neff 2002, and references therein); in marine organisms, As is present as both inorganic species such as arsenate $\left(\mathrm{As}^{\mathrm{V}}\right)$ and arsenite (As $\left.{ }^{\mathrm{III}}\right)$ (e.g., Sanders 1979; Raab et al. 2005; Duncan et al. 2015) and organic species,

\footnotetext{
* Correspondence: harue@sci.osaka-cu.ac.jp

'Department of Biology and Geosciences, Graduate School of Science, Osaka City University, 3-3-138 Sugimoto, Sumiyoshi-ku, Osaka 558-8585, Japan Full list of author information is available at the end of the article
}

such as arsenosugars in marine algae (e.g., Morita and Shibata 1990; Edmonds et al. 1997; Raab et al. 2005) and arsenobetaine in marine animals (e.g., Edmonds et al. 1977; Duncan et al. 2015).

In general, the dominant As phases in sediments are the inorganic species: that is, arsenite in reducing environments and arsenate in oxidizing environments (Neff 2002). Unpolluted nearshore marine and estuarine sediments usually contain from 5 to $15 \mu \mathrm{g} / \mathrm{g}$ As, but deep-sea sediments occasionally contain much higher concentrations, probably owing to precipitation from submarine hydrothermal solutions. Neff (2002) documented As phase changes in marine sediments due to microbial decomposition and synthesis of organoarsenicals and reported that sulfides such as realgar $\left(\mathrm{As}_{4} \mathrm{~S}\right)$ and pyrite $\left(\mathrm{FeS}_{2}\right)$, in which As was included as an impurity element, and oxides such as arsenolite $\left(\mathrm{As}_{2} \mathrm{O}_{3}\right)$ are the main final inorganic products fixed in the sediments.

In coastal areas, As in sediments and interstitial water has been studied mainly in relation to biotoxicity. In deep-sea environments, although As has been documented 
in seafloor surface sediments (e.g., Francesconi and Edmonds 1996) and in hydrothermal sediments (e.g., Handley and Lloyd, 2013), vertical profiles of As in deep-sea sediments have not been systematically studied. In this study, we first traced concentrations and chemical forms of As in deep-sea sediments from the seafloor surface, through a methane hydrate layer, and down to $2200 \mathrm{mbsf}$. Then, we examined the sources of As and effect of microbial activity on its behavior in deep-sea sediments.

\section{Samples and analytical methods \\ Drilling sites and studied cores}

The sediment cores used in this study were collected from three different drilling sites around the Nankai Trough (Sites C0002, C0021, and C0022) by D/V Chikyu during various Integrated Ocean Drilling Program (IODP) expeditions (Fig. 1).

The longest core was from Site C0002 in the Kumano Forearc Basin. The sediments at this site were lithologically categorized into five units (Moore et al. 2013; Expedition 348 Scientists and Scientific Participants 2014): in descending order, Unit I (shallower than $126 \mathrm{mbsf}$ ) consists of hemipelagic mud with fine sand, silt, and volcanic ash deposited since $1 \mathrm{Ma}$; Unit II (126-826 mbsf), which has a similar lithology to Unit I but consists of more consolidated sediments, was deposited between 1.67 and $1 \mathrm{Ma}$; Unit III (826-1025.5 mbsf) is composed of slope sediments deposited during a period of slow sedimentation from 3.65 to $1.67 \mathrm{Ma}$; Unit IV (1025.5$1740.5 \mathrm{mbsf}$ ) is composed of accretionary prism sediments older than $5.6 \mathrm{Ma}$ (Ashi et al. 2008); and Unit V (1740.5-2220 mbsf) consists of accretionary prism sediments older than those of Unit IV. Cuttings and logging data suggest that Unit $\mathrm{V}$ is somewhat sandy with many conductive fractures. A bottom-simulating reflector (Moore et al. 2009; Strasser et al. 2014) and onboard infrared-camera observations of low-temperature anomalies at 369, 388, and $392 \mathrm{mbsf}$ in the recovered sediment cores (Moore et al. 2013) confirm the presence of methane hydrate at 200 to $400 \mathrm{mbsf}$ in Unit II. Reduced chlorinity in interstitial water (IW) from 200 to $400 \mathrm{mbsf}$ also supports the presence of the methane hydrate in this depth interval (Fig. 2, Moore et al. 2013).

Site C0022 is located on the toe of the forearc slope of the Nankai Trough (Fig. 1). On the basis of their overall lithology, the cored sediments down to 415.9 mbsf were classified into a single unit, although two subunits were identified in logging data during drilling (Moore et al. 2013): Subunit II-a (0-383.5 mbsf) is composed dominantly of silty clay with variable amounts of calcareous nannofossils, foraminifers, siliceous biogenic debris, and volcanic ash; Subunit II-b (383.5-415.9 mbsf) consists of a series of mud-encrusted gravels interbedded with thin sand, clayey silt, and silty clay layers in its upper part and with mainly silty clay layers in its lower part. Several shear zones and minor faults indicate the presence of a splay fault in the interval from 80 to 140 mbsf. Below this fracture zone, chlorinity of the IW was higher than that of ambient seawater (Fig. 3c), presumably because of upwelling of deep-seated water along the fault (Moore et al. 2013).

Site C0021, located on the basin slope seaward of the splay fault, is composed of dominantly silty clay sediments that were relocated by a submarine landslide (Moore et al. 2013). The chlorinity of the IW, which was the same as that of seawater, was uniform from the seafloor to $200 \mathrm{mbsf}$ (Fig. 3g), probably as a result of homogenization of the collapsed sediments.

Most core samples used for our As analyses were collected by IODP Expedition 338 (October 2012 to January 2013) from Hole C0021B (drilled interval 0-204 mbsf), Hole C0022B (drilled interval 0-204 mbsf), Holes C0002K, L (200-505 mbsf), and holes C0002J and $\mathrm{H}$ (902-940 and 1100.5-1120 mbsf, respectively) (Moore et al. 2013). Both stored and newly recovered cores from Site C0002 were analyzed to document As behavior from the seafloor to as deep as possible in the ocean bottom sediments. Sediment samples from 0 to $204 \mathrm{mbsf}$ and 475-1057 mbsf in Holes C0002D and B, respectively, were collected by Expedition 315 (November-December 2007) (Ashi et al. 2008), and those from 2110 to 2220 mbsf in Holes C0002P were collected by Expedition 348 (September 2013 to January 2014) (Expedition 348 Scientists and Scientific Participants 2014).

\section{Analytical methods}

In order to examine As in coexisting water and solids, we analyzed As in both IW and the squeezed cake (SC, residual sediment after extraction of IW). IW was extracted from the sediment cores on board with a Manheim-type titanium squeezer (Manheim 1966), filtered through a polytetrafluoroethylene (PTFE) membrane filter $(0.45 \mu \mathrm{m}$ mesh), preserved with $\mathrm{HCl}$ in a plastic vial (Nalgene), and stored at room temperature. The SC was stored onboard at $-20^{\circ} \mathrm{C}$ during the cruises. Then, in the shore-based laboratory, the SC was freeze-dried and powdered manually for the analyses. In our analyses, we used stored IW from shallow sediments above 200 mbsf in Site C0002 that had previously been used for onboard analysis of alkalinity. Among the samples taken during Expedition 348, we analyzed only the $\mathrm{SC}$, because these core samples rarely contained an extractable amount of IW.

We determined total As concentrations in the bulk sediment (i.e., SC) and dissolved in the IW, As species extracted from the sediments by a sequential chemical extraction method, and As species in the sediments separated by high-performance liquid chromatography (HPLC) as described below. 

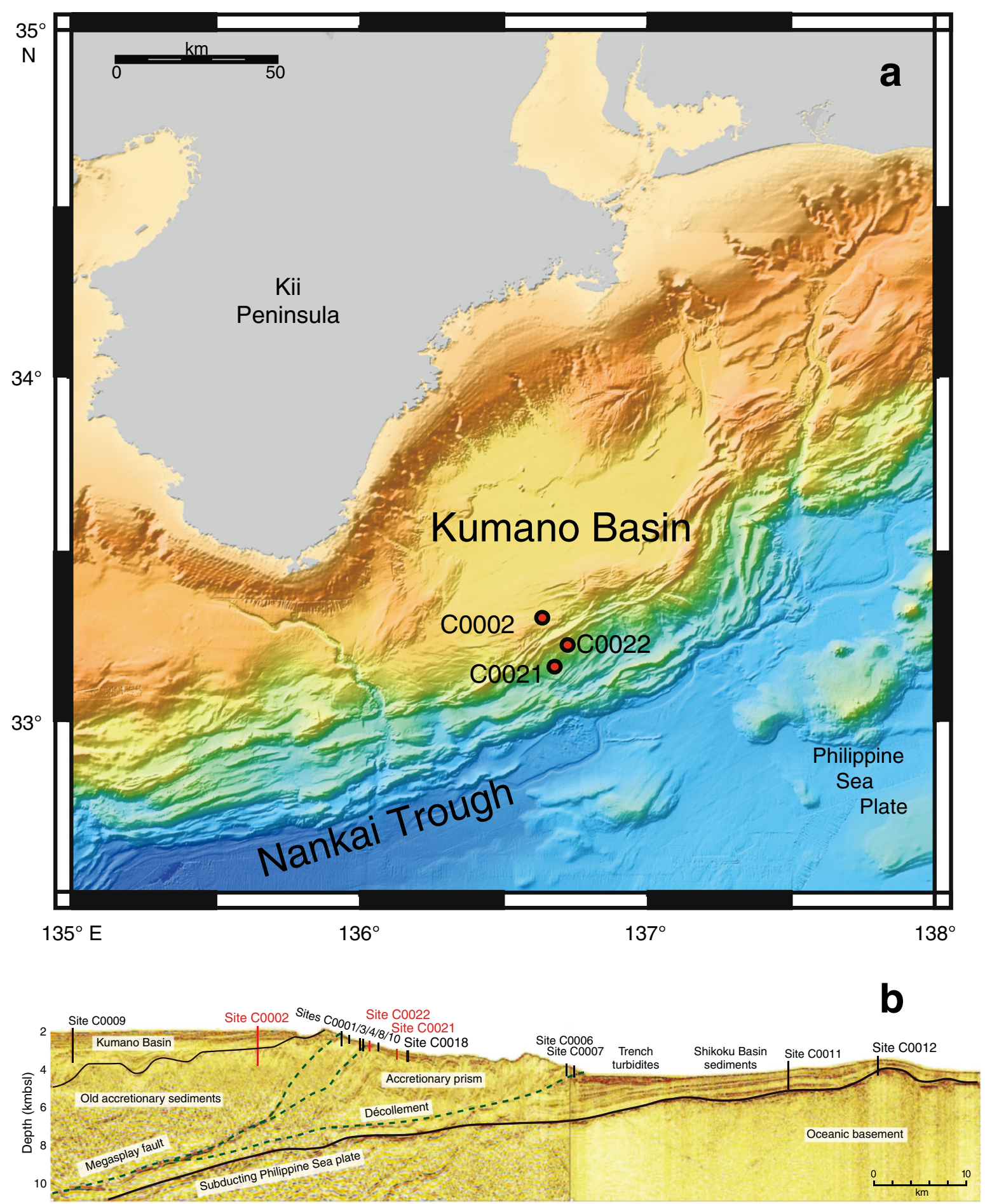

Fig. 1 Location of study sites (Sites C0002, C0021, and C0022, Kumano Basin, Nankai Trough) (a) and geological profile of the area (b) (Strasser et al. 2014)

\section{Total As concentration}

One gram of powdered sediment was fused with $\mathrm{NaCO}_{3}$ at $900{ }^{\circ} \mathrm{C}$ until the silicates were completely melted, and then the residue was dissolved in $0.05 \mathrm{M} \mathrm{HNO}_{3}$. IW was diluted with $0.05 \mathrm{M} \mathrm{HNO}_{3}$ to make a $1 / 300$ solution. Total As concentrations in the sample solutions were quantified by inductively coupled plasma-mass spectrometry (ICP-MS; SPQ9700, Hitachi), with $\mathrm{H}_{2}$ gas used to prevent the formation of $\mathrm{ArCl}^{+}$. Commercially distributed standard As solution (FUJIFILM Wako Pure Chemical Corp.) was used for the calibration. Accuracy of the results was checked by using rock standard samples 


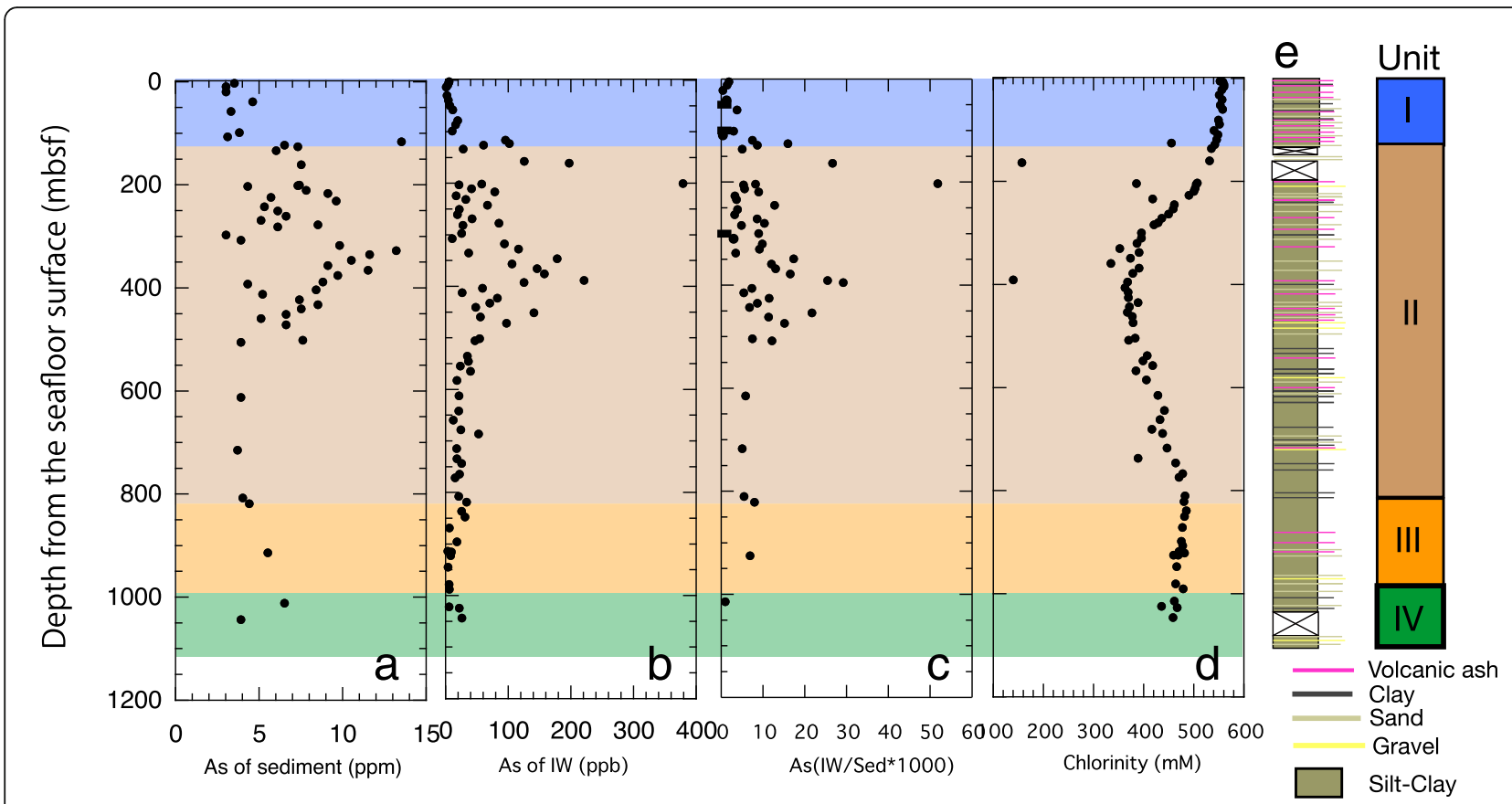

Fig. 2 Arsenic concentrations of sediments (squeezed cakes) (a) and interstitial water (b), ratio of arsenic concentrations of IW and sediment (c), and chlorinity (d) of Sites C0002, Kumano Basin, Nankai Trough, in relation to the depth, lithology and its related components (e) Lithology was referred to Strasser et al. (2014)

(JSd-1, As $2.42 \mathrm{ppm} ;$ JSd-2, $38.6 \mathrm{ppm}$; and JSl-1, 14.9 ppm) from AIST (National Institute of Advanced Industrial Science and Technology), which were prepared in a similar manner to the studied samples. The analytical error was $\pm 8 \%$ at maximum.

\section{Sequential chemical extraction of As}

The BCR sequential chemical extraction method (Rauret et al. 1999) was used to separate chemical phases of As in sediment. This method cannot accurately specify the As host phases, but As behaviors associated with changes in the environmental redox condition can be roughly evaluated. As phases were extracted in five steps. In step $1,1 \mathrm{~g}$ of sediment powder was put in a PTFE centrifuge tube, which was shaken with $20 \mathrm{ml}$ $0.22 \mathrm{M}$ acetic acid ( $\mathrm{pH}$ adjusted to 5 with $\mathrm{HNO}_{3}$ ) for 16 $\mathrm{h}$ at room temperature. Then, the mixture was centrifuged at $10,000 \mathrm{rpm}$ for $10 \mathrm{~min}$ to extract acid-soluble phases, namely, components weakly adsorbed onto detrital materials or contained in carbonates into the supernatant fluid. In step 2, the residual sediment was washed with ultra-pure water; then, $20 \mathrm{ml} 0.5 \mathrm{M}$ hydroxylammonium chloride $\left(\mathrm{NH}_{3} \mathrm{OHCl}, \mathrm{pH}\right.$ adjusted to 2 with $\mathrm{HNO}_{3}$ ) was added and the mixture was shaken for $16 \mathrm{~h}$ at room temperature to extract As fixed in reducible phases, mainly, Fe-oxyhydroxides and Mn-oxides. In step 3 , the residue from the previous step was heated with $20 \mathrm{ml} 0.1 \mathrm{M}$ sodium pyrophosphate solution for $2 \mathrm{~h}$ and then shaken with $5 \mathrm{M}$ ammonium acetate $\left(\mathrm{CH}_{3} \mathrm{COONH}_{4}, \mathrm{pH} 2\right)$ for $16 \mathrm{~h}$. This reagent cannot completely decompose sulfide minerals, so the most probable phase dissolved at this step is organic matter. Then, the mixture of residue and solution was centrifuged to separate. In step 4, the residue from step 3 was shaken with a mixture of concentrated nitric and perchloric acid for 16 $\mathrm{h}$, then gently heated for $24 \mathrm{~h}$, and centrifuged. Most insoluble phases, silicates, and sulfides were decomposed at this step. In step 5 , the residue from the previous step was decomposed by alkaline fusion to decompose minerals resistant to the reagents used in steps 1-4. The As extracted at each step was quantified by ICP-MS as described in the previous section.

\section{As species in sediments}

Water-soluble As compounds in SC from Sites C0002 and $\mathrm{C} 0022$ were extracted by the method of Ellwood and Maher (2003). The sediment sample was mixed with a solution of $0.1 \mathrm{M}$ hydroxylammonium chloride and $0.5 \mathrm{M}$ phosphoric acid in a PTFE centrifuge tube and shaken at $25^{\circ} \mathrm{C}$ for $1 \mathrm{~h}$. The hydroxylammonium chloride solution is reductant and can decompose amorphous and weakly crystalized Fe-oxyhydroxides (e.g., ferrihydrite and goethite) and Mn-oxides, and the phosphoric acid helps to preserve $\mathrm{As}^{\mathrm{III}}$ and $\mathrm{As}^{\mathrm{V}}$ species, especially in solutions containing high amounts of Fe and Mn (Ellwood and Maher 2003). Frozen sediment was used for this analysis, because dried samples may become 


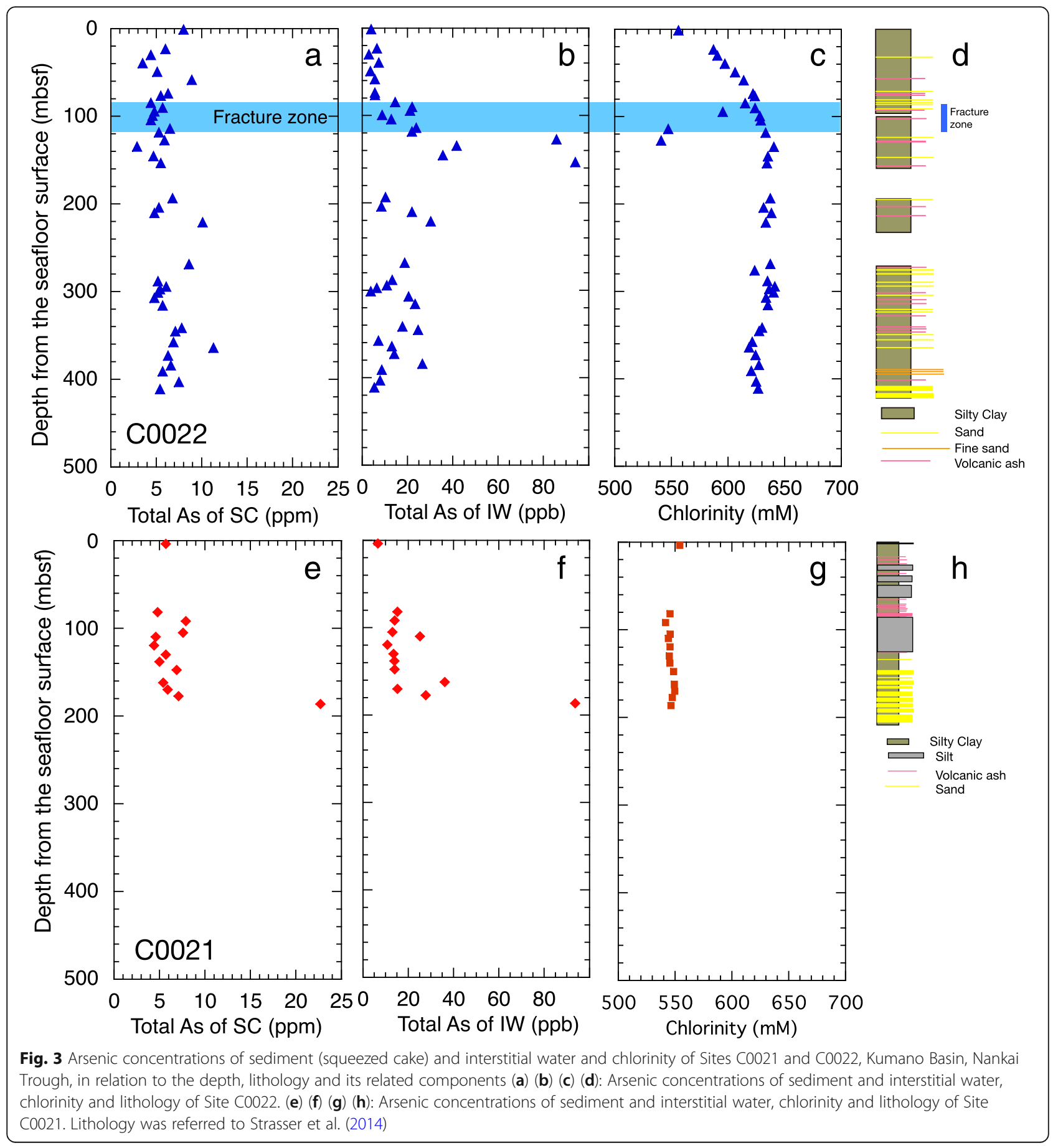

oxidized, changing the chemical form of the As. After the reaction, the solid phase was separated by centrifugation $(1880 \times g$ for $10 \mathrm{~min})$ and removed by filtration through a PTFE membrane filter $(0.45 \mu \mathrm{m}$ mesh). The obtained solution was analyzed by HPLC-ICP-MS at the National Institute for Environmental Studies (8800 ICP-QQQ, Agilent Technologies, Inc., USA) to determine the concentrations of each separated As phase. Eight As compounds (commercially distributed by
FUJIFILM Wako Pure Chemical Corp.), As(III), As(V), methylarsonic acid (MMA), dimethylarsinic acid (DMA), arsenobetaine (AsB), trimethylarsine oxide (TMO), tetramethylarsonium salt (TMAO), and arsenocholine (AsC), were separated in a GL-Science InertSil AS column (4.6 i.d. $\times 250 \mathrm{~mm}$ long), using an eluent composed of $10 \mathrm{mM}$ butane-1-sulfonic acid sodium salt, $4 \mathrm{mM}$ malonic acid, $4 \mathrm{mM}$ tetramethylammonium hydroxide, and $0.05 \%$ methanol. The flow rate was $1.0 \mathrm{ml} / \mathrm{min}$ at $40{ }^{\circ} \mathrm{C}$. 


\section{Results}

\section{Bulk As concentration}

The bulk As concentrations in SC from Hole C0002 ranged from 3 to $14 \mathrm{ppm}$ (average $6.4 \mathrm{ppm}$ ) (Table 1, Fig. 2a), which is within the range of reported concentration in seafloor surface sediments surrounding the Japanese islands; for example, an average concentration of As of $5.5 \mathrm{ppm}$ (range, 0-14 ppm, except one sample with $23.3 \mathrm{ppm}$ ) has been reported for 95 surface sediment samples from Kumano-nada (the sea area around the study area) (AIST 2018).

The highest As concentration was measured in SC from 116 mbsf, at the bottom of Unit I (13.5 ppm), but the As concentration range in SC from other parts of Unit I was low (3-5 ppm). In the upper half of Unit II, between 110 and 500 mbsf (referred to as Unit II-1 hereafter), the As concentration was $>5 \mathrm{ppm}$, and a maximum concentration of $13.2 \mathrm{ppm}$ was observed at 320 mbsf. Arsenic concentrations of SC from below 600 mbsf in Hole C0002 were mostly $<5$ ppm, similar to those of SC from Unit I. The bulk As concentration in sediments from below 2000 mbsf was also mostly <6 ppm, while it increased in the deeper part and the maximum concentration was up to $11 \mathrm{ppm}$ (Table 1). Although only bulk As concentrations were obtained from the deepest sediments, we inferred that As behavior did not largely change below $~ 500$ mbsf in Hole C0002.

The total dissolved As concentration of IW from Hole C0002 ranged from 0.9 to $379 \mathrm{ppb}$ (average $50 \mathrm{ppb}$ ). The total As concentration was low in the Unit I sediments and in the sediments from below 500 mbsf (Units II-2 and III), whereas it was high in the Unit II-1 sediments (Fig. 2b). The relationship between the SC concentration and the IW concentration varied with depth (Fig. 2c): for example, As peaks in IW were observed at 200 and 400 mbsf, whereas sediment peaks were observed at 116 and $<350$ mbsf. The low As concentrations in SC from Unit I (excepting three samples from the bottom of the unit) and from below 500 mbsf did not change with depth. Owing to the insoluble host phases of the As and the physico-chemical conditions of the ambient IW, As in these depth intervals would not be easily mobilized.

At Site C0022, the drilled hole penetrated the fracture zone of a splay fault at around $100 \mathrm{mbsf}$ (Fig. 3). The chlorinity of the IW increased with depth from $550 \mathrm{mM}$, that of ambient seawater, to $600 \mathrm{mM}$ in the fracture zone, reflecting the upwelling of deep-seated water, in which dissolved salts had been concentrated via hydration reactions, along the fault (Strasser et al. 2014). The total As concentration in SC and IW ranged from 3 to $11 \mathrm{ppm}$ and 4 to $94 \mathrm{ppb}$, respectively. The total concentration in SC did not change with depth, whereas that in IW increased below $100 \mathrm{mbsf}$ and reached a peak at 110-130 mbsf, below the fracture zone.
Total As concentrations of SC and IW from Hole C0021 were from 4 to $7 \mathrm{ppm}$ and from 7 to $36 \mathrm{ppb}$, respectively, except the deepest sample (22.7 ppm and 94 ppb), and did not change substantially with depth (Fig. 3). This site is located on the forearc slope, and the cored sediments consist of landslide deposits. The chlorinity is stable with depth and the same as that of seawater, probably because the sediment and IW were homogenized during relocation by the landslide. Thus, except in the deepest samples (from $180 \mathrm{mbsf}$ ), the As concentrations in the sediment (4-9 ppm) and IW (5-20 ppb) can be regarded as averaged shallow sediment values.

\section{Host phases of As in the sediments}

Total As recovery by sequential extraction is reported as a percentage relative to the bulk As concentration (Table 2). In the sequential chemical extraction of As phases from sediments of Hole C0002, the total recovery of As ranged from 65.4 to $146.7 \%$ (average and $1 \sigma$ : $104 \pm 20 \%$, Table 2 and Fig. 4). Among the totally extracted As, recovery in steps 1, 2, and 3, which extracted the mobile As phases in association with changing redox and $\mathrm{pH}$ conditions of coexisting solution, ranged from 10 to 70\%; As recovery in steps 2 and 3 averaged $21 \%$ and 19\%, respectively. Further, As extracted in step 3, of which main host phase is organic matter, seemed to increase as the total As concentration of the sample increased $(r=0.72)$; this result implies that biogenic As was responsible for the high accumulation rate of As in this sediment column. The high concentrations of As extracted from Unit II in step 2, which extracted As associated with Fe-oxyhydroxides/Mn oxides, imply that oxidation of Fe-minerals occurred in this unit.

\section{As species in sediments separated by HPLC}

The mixture of hydroxyl-ammonium chloride solution and phosphoric acid leaches inorganic and organic phases adsorbed onto Fe-hydroxides and other particles. The leached phases may correspond partly to As extracted by steps 1,2 , and 3 of the sequential extraction procedure. Only sediments from Unit II of C0002 (recovery $30-100 \%$ ) and from C0022 (recovery 20 to $80 \%$ ) were analyzed by this procedure. These recoveries are generally high compared with the summed As concentrations sequentially extracted by steps 1,2 , and 3 (Table 3), probably because the analytical error of the leaching procedure is slightly higher than that for the total As concentration measurement.

Even considering the large analytical error, it is notable that the most abundant leached As phase was arsenate $\left(A s^{\mathrm{V}}\right)$ (Fig. 5); this result indicates that the As was mostly adsorbed onto or fixed in Fe-oxyhydroxides in the 
Table 1 Total arsenic concentration of squeezed cake and interstitial water of sediments from the Sites C0002, C0021 and C0022 at Nankai Trough

\begin{tabular}{|c|c|c|c|}
\hline \multirow[t]{2}{*}{ Sample name } & \multirow{2}{*}{$\begin{array}{l}\text { Depth } \\
\text { (mbsf) }\end{array}$} & \multicolumn{2}{|l|}{ As concentration } \\
\hline & & $\begin{array}{l}\text { Squeezed cake } \\
\text { (ppm) }\end{array}$ & $\begin{array}{l}\text { Interstitial water } \\
(\mathrm{ppb})\end{array}$ \\
\hline C0002D-1H-2 & 2 & 3.5 & 5.1 \\
\hline C0002D-1H-5 & 4 & & 4.8 \\
\hline C0002D-2H-3 & 9 & 3.0 & 3.1 \\
\hline $\mathrm{C} 0002 \mathrm{D}-2 \mathrm{H}-7$ & 13 & & 0.9 \\
\hline C0002D-3H-4 & 19 & 3.0 & \\
\hline C0002D-4H-4 & 29 & & 2.0 \\
\hline C0002D-5H-4 & 38 & 4.6 & 4.0 \\
\hline C0002D-6H-5 & 49 & & 6.4 \\
\hline C0002D-7H-4 & 57 & 3.3 & 11.1 \\
\hline C0002D-9H-5 & 78 & & 18.8 \\
\hline $\mathrm{C} 0002 \mathrm{D}-10 \mathrm{H}-4$ & 86 & & 15.5 \\
\hline C0002D-11H-5 & 98 & 3.8 & 10.0 \\
\hline C0002D-12H-5 & 106 & 3.1 & \\
\hline C0002D-13H-5 & 116 & 13.5 & 95.4 \\
\hline C0002D-14H-3 & 122 & 6.5 & 101.5 \\
\hline C0002D-14H-5 & 125 & 7.3 & 60.1 \\
\hline C0002D-15X-5 & 133 & 6.0 & 27.8 \\
\hline C0002D-16H-6 & 157 & & 125.1 \\
\hline C0002D-17X-4 & 160 & 7.5 & 196.8 \\
\hline $\mathrm{C} 0002 \mathrm{D}-18 \mathrm{H}-1$ & 200 & 7.4 & 378.7 \\
\hline C0002D-18H-2 & 201 & 7.3 & 57.5 \\
\hline $\mathrm{C} 0002 \mathrm{~K}-1 \mathrm{H}-3$ & 202 & 4.3 & 21.2 \\
\hline C0002K-3T-5 & 210 & 7.8 & 41.0 \\
\hline C0002K-4T-2 & 216 & 9.1 & 77.9 \\
\hline C0002K-5T-6 & 224 & 5.7 & 16.3 \\
\hline C0002K-6T-3 & 231 & 9.6 & 31.9 \\
\hline C0002K-7X-5 & 242 & 5.3 & 66.3 \\
\hline C0002K-8X-2 & 250 & 6.1 & 21.4 \\
\hline C0002K-9X-3 & 260 & 6.6 & 18.6 \\
\hline C0002K-10X-2 & 268 & 5.1 & 41.6 \\
\hline C0002K-11X-2 & 277 & 8.5 & 84.8 \\
\hline C0002L-1X-4 & 281 & 6.1 & 27.4 \\
\hline C0002L-3X-2 & 297 & 3.0 & 25.3 \\
\hline C0002L-4X-2 & 307 & 3.9 & 10.3 \\
\hline C0002L-5X-3 & 317 & 9.8 & 93.6 \\
\hline C0002L-6X-4 & 327 & 13.2 & 115.9 \\
\hline C0002L-7X-2 & 335 & 11.6 & 36.4 \\
\hline C0002L-8X-4 & 346 & 10.5 & 177.8 \\
\hline C0002L-9X-5 & 356 & 9.1 & 105.7 \\
\hline C0002L-10X-3 & 365 & 11.5 & 145.5 \\
\hline C0002L-11X-4 & 375 & 9.7 & 157.2 \\
\hline
\end{tabular}

Table 1 Total arsenic concentration of squeezed cake and interstitial water of sediments from the Sites C0002, C0021 and C0022 at Nankai Trough (Continued)

\begin{tabular}{|c|c|c|c|}
\hline \multirow[t]{2}{*}{ Sample name } & \multirow{2}{*}{$\begin{array}{l}\text { Depth } \\
\text { (mbsf) }\end{array}$} & \multicolumn{2}{|c|}{ As concentration } \\
\hline & & $\begin{array}{l}\text { Squeezed cake } \\
\text { (ppm) }\end{array}$ & $\begin{array}{l}\text { Interstitial water } \\
\text { (ppb) }\end{array}$ \\
\hline C0002L-12X-7 & 388 & 8.8 & 220.4 \\
\hline C0002P 2R-1 & 2173 & 2.5 & \\
\hline C0002P 2R-2 & 2175 & 2.5 & \\
\hline C0002P 2R-3 & 2176 & 3.6 & \\
\hline C0002P 2R-4 & 2177 & 8.7 & \\
\hline C0002P 3R-1 & 2182 & 6.6 & \\
\hline C0002P 4R-1 & 2192 & 4.9 & \\
\hline C0002P 4R-4 & 2196 & 4.3 & \\
\hline C0002P 4R-6 & 2199 & 5.4 & \\
\hline C0002P 4R-7 & 2203 & 2.5 & \\
\hline C0002P 4R-8 & 2212 & 6.4 & \\
\hline C0002P 4R-9 & 2213 & 11.6 & \\
\hline C0002P 4R-10 & 2214 & 8.0 & \\
\hline C0002P 4R-11 & 2217 & 8.9 & \\
\hline C0021B-1H-4 & 3.7 & 5.7 & 6.6 \\
\hline C0021B-2H-3 & 81.6 & 4.8 & 15.2 \\
\hline C0021B-3H-4 & 91.7 & 7.9 & 14.0 \\
\hline C0021B-4H-6 & 104.9 & 7.6 & 13.0 \\
\hline C0021B-5H-2 & 109.9 & 4.6 & 25.2 \\
\hline C0021B-6H-3 & 119.5 & 4.4 & 10.8 \\
\hline C0021B-7H-4 & 129.9 & 5.7 & 13.5 \\
\hline C0021B-8H-2 & 138.0 & 5.0 & 13.9 \\
\hline C0021B-9H-2 & 147.5 & 6.9 & 14.0 \\
\hline $\mathrm{C} 0021 \mathrm{~B}-10 \mathrm{H}-8$ & 162.1 & 5.4 & 36.1 \\
\hline $\mathrm{C} 0021 \mathrm{~B}-12 \mathrm{H}-2$ & 170.0 & 5.9 & 15.3 \\
\hline C0021B-13T-3 & 177.4 & 7.1 & 27.8 \\
\hline C0021B-14T-2 & 186.4 & 22.7 & 93.7 \\
\hline C0022B-1H-2 & 1.2 & 8.0 & 4.0 \\
\hline C0022B-2H-5 & 23.4 & 6.0 & 6.5 \\
\hline C0022B-3H-2 & 30.3 & 4.4 & 3.0 \\
\hline C0022B-4H-2 & 39.5 & 3.5 & 7.4 \\
\hline C0022B-5H-2 & 49.3 & 5.1 & 3.7 \\
\hline C0022B-6H-2 & 58.6 & 8.9 & 5.6 \\
\hline C0002L-13X-1 & 392 & 4.3 & 124.8 \\
\hline C0002L-14X-3 & 403 & 8.4 & 58.4 \\
\hline C0002L-15X-4 & 412 & 5.2 & 25.8 \\
\hline C0002L-16X-3 & 422 & 7.4 & 82.3 \\
\hline C0002L-17X-4 & 432 & 8.5 & 70.0 \\
\hline C0002L-18X-3 & 440 & 7.5 & 47.8 \\
\hline C0002L-19X-3 & 451 & 6.6 & 140.6 \\
\hline C0002L-20X-2 & 459 & 5.1 & 55.3 \\
\hline
\end{tabular}


Table 1 Total arsenic concentration of squeezed cake and interstitial water of sediments from the Sites C0002, C0021 and C0022 at Nankai Trough (Continued)

\begin{tabular}{|c|c|c|c|}
\hline \multirow[t]{2}{*}{ Sample name } & \multirow{2}{*}{$\begin{array}{l}\text { Depth } \\
\text { (mbst) }\end{array}$} & \multicolumn{2}{|c|}{ As concentration } \\
\hline & & $\begin{array}{l}\text { Squeezed cake } \\
\text { (ppm) }\end{array}$ & $\begin{array}{l}\text { Interstitial water } \\
(\mathrm{ppb})\end{array}$ \\
\hline C0002L-21X-4 & 471 & 6.6 & 96.9 \\
\hline C0002L-24X-5 & 501 & 7.6 & 54.2 \\
\hline C0002B-4R-2 & 505 & 3.9 & 46.2 \\
\hline C0002B-8R-2 & 535 & & 34.4 \\
\hline C0002B-9R-3 & 545 & & 35.9 \\
\hline C0002B-10R-2 & 554 & & 23.1 \\
\hline C0002B-11R-3 & 564 & & 39.2 \\
\hline C0002B-13R-2 & 582 & & 17.8 \\
\hline C0002B-16R-3 & 612 & 3.9 & 21.1 \\
\hline C0002B-19R-3 & 641 & & 20.7 \\
\hline C0002B-21R-3 & 659 & & 12.1 \\
\hline C0002B-23R-3 & 678 & & 23.9 \\
\hline C0002B-24R-2 & 686 & & 52.3 \\
\hline C0002B-27R-2 & 714 & 3.7 & 17.3 \\
\hline C0002B-29R-2 & 734 & & 17.8 \\
\hline C0002B-30R-2 & 743 & & 25.4 \\
\hline C0002B-32R-5 & 764 & & 21.7 \\
\hline C0002B-33R-2 & 771 & & 14.8 \\
\hline C0002B-37R-2 & 807 & 4.0 & 20.4 \\
\hline C0002B-38R-3 & 818 & 4.4 & 33.3 \\
\hline C0002B-40R-2 & 836 & & 25.3 \\
\hline C0002B-41R-3 & 847 & & 30.5 \\
\hline C0002B-43R-5 & 868 & & 5.5 \\
\hline C0002B-46R-4 & 895 & & 17.6 \\
\hline C0002B-48R-5 & 915 & & 8.8 \\
\hline C0002B-49R-3 & 922 & & 7.7 \\
\hline C0002B-51R-5 & 944 & & 3.5 \\
\hline C0002B-55R-2 & 978 & & 5.1 \\
\hline C0002B-56R-2 & 987 & & 5.5 \\
\hline C0002B-59R-2 & 1011 & 6.5 & \\
\hline C0002B-61R-3 & 1021 & & 5.3 \\
\hline C0002B-62R-2 & 1024 & & 21.3 \\
\hline C0002B-64R-2 & 1043 & 3.9 & 25.5 \\
\hline C0002J-3R-3 & 913.6 & 5.5 & 3.3 \\
\hline C0022B-7H-7 & 74.0 & 6.3 & 5.6 \\
\hline C0022B-8H-1 & 76.5 & 5.5 & 5.7 \\
\hline C0022B-9T-2 & 84.8 & 4.4 & 14.6 \\
\hline C0022B-10T-2 & 90.3 & 5.7 & 22.1 \\
\hline C0022B-11T-1 & 94.5 & 4.8 & 21.2 \\
\hline C0022B-12T-1 & 99.5 & 4.6 & 8.8 \\
\hline
\end{tabular}

Table 1 Total arsenic concentration of squeezed cake and interstitial water of sediments from the Sites C0002, C0021 and C0022 at Nankai Trough (Continued)

\begin{tabular}{|c|c|c|c|}
\hline \multirow[t]{2}{*}{ Sample name } & \multirow{2}{*}{$\begin{array}{l}\text { Depth } \\
\text { (mbst) }\end{array}$} & \multicolumn{2}{|c|}{ As concentration } \\
\hline & & $\begin{array}{l}\text { Squeezed cake } \\
\text { (ppm) }\end{array}$ & $\begin{array}{l}\text { Interstitial water } \\
(\mathrm{ppb})\end{array}$ \\
\hline C0022B-13T-1 & 104.5 & 4.4 & 12.8 \\
\hline C0022B-14X-4 & 114.1 & 6.5 & 23.9 \\
\hline C0022B-15X-3 & 118.5 & 5.3 & 22.0 \\
\hline C0022B-16X-4 & 127.5 & 5.9 & 85.8 \\
\hline C0022B-17X-2 & 134.8 & 2.9 & 41.7 \\
\hline C0022B-18X-4 & 145.6 & 4.7 & 35.6 \\
\hline C0022B-19X-2 & 153.4 & 5.5 & 94.1 \\
\hline C0022B-20X-4 & 193.6 & 6.8 & 10.3 \\
\hline C0022B-21X-6 & 204.3 & 5.3 & 8.5 \\
\hline C0022B-22X-1 & 210.5 & 4.8 & 22.0 \\
\hline C0022B-23X-4 & 221.2 & 10.1 & 30.3 \\
\hline C0022B-24X-3 & 268.7 & 8.6 & 18.8 \\
\hline C0022B-26X-3 & 288.3 & 5.2 & 13.3 \\
\hline C0022B-27X-4 & 294.3 & 6.1 & 10.9 \\
\hline C0022B-28X-3 & 297.4 & 5.4 & 6.4 \\
\hline C0022B-29X-2 & 301.3 & 5.2 & 3.8 \\
\hline C0022B-30X-3 & 307.3 & 4.8 & 20.5 \\
\hline C0022B-31X-2 & 315.9 & 5.7 & 23.4 \\
\hline C0022B-33X-7 & 341.7 & 7.8 & 17.8 \\
\hline C0022B-34X-3 & 345.4 & 7.1 & 24.7 \\
\hline C0022B-35X-5 & 357.8 & 6.9 & 7.2 \\
\hline C0022B-36X-3 & 364.2 & 11.3 & 13.1 \\
\hline C0022B-37X-2 & 373.1 & 6.3 & 14.2 \\
\hline C0022B-38X-3 & 384.3 & 6.6 & 26.6 \\
\hline C0022B-39X-2 & 391.0 & 5.7 & 8.7 \\
\hline C0022B-40X-3 & 403.2 & 7.5 & 7.9 \\
\hline C0022B-41X-2 & 411.4 & 5.4 & 5.4 \\
\hline
\end{tabular}

sediments. In addition, chromatogram peaks indicating small amounts of MMA and AsB and two unidentified As compounds were detected. Chromatogram peaks for the identifiable compounds were confirmed by co-injection of standards of As-compounds. The presence of above organoarsenicals indicates that As in the sediment column had a biological source.

\section{Discussion}

We examined the factors controlling As behavior in deep-sea sediments mainly on the basis of the analytical results for the cored sediments from Hole C0002. Vertical profiles of As and other chemical components in IW from the sediment column at Site C0002 are shown in Fig. 6 (Moore et al. 2013). As described above, chlorinity 
Table 2 Arsenic concentrations of sequentially extracted fractions of sediments from Site C0002 at Nankai Trough

\begin{tabular}{|c|c|c|c|c|c|c|c|c|c|}
\hline \multirow[t]{2}{*}{ Sample name } & \multirow{2}{*}{$\begin{array}{l}\text { Depth } \\
\text { (mbsf) }\end{array}$} & \multirow{2}{*}{$\begin{array}{l}\text { Total } \\
\text { As(ppm) }\end{array}$} & \multicolumn{6}{|c|}{ As concentration (ppm) } & \multirow[t]{2}{*}{ Recovery (\%) } \\
\hline & & & Step 1 & Step 2 & Step 3 & Step 4 & Step 5 & $\overline{\text { Total }}$ & \\
\hline C0002D 1H-2 & 2 & 3.5 & 0.18 & 1.27 & 0.36 & 1.67 & 0.29 & 3.76 & 107.3 \\
\hline $\mathrm{C} 0002 \mathrm{D} 5 \mathrm{H}-4$ & 38 & 4.6 & 0.10 & 0.15 & 1.03 & 3.80 & 0.76 & 5.84 & 127.7 \\
\hline $\mathrm{C} 0002 \mathrm{D} 7 \mathrm{H}-4$ & 57 & 3.3 & 0.13 & 0.57 & 0.42 & 2.34 & 0.54 & 3.99 & 121.9 \\
\hline C0002D 11H-5 & 98 & 3.8 & 0.12 & 0.76 & 0.54 & 2.31 & 0.72 & 4.46 & 116.2 \\
\hline C0002D 12H-5 & 106 & 3.1 & 0.11 & 0.49 & 0.97 & 1.86 & 0.67 & 4.10 & 132.7 \\
\hline C0002D 13H-5 & 116 & 13.5 & 0.15 & 1.24 & 6.12 & 2.64 & 0.66 & 10.81 & 80.2 \\
\hline C0002D 15X-5 & 133 & 6.0 & 0.08 & 1.23 & 0.57 & 1.88 & 0.82 & 4.58 & 76.7 \\
\hline C0002D 17X-4 & 160 & 7.5 & 0.44 & 3.69 & 1.30 & 2.19 & 0.31 & 7.92 & 105.8 \\
\hline C0002D 18H-1 & 200 & 7.4 & 0.21 & 2.24 & 1.14 & 4.18 & 0.33 & 8.11 & 110.2 \\
\hline C0002D 18H-2 & 201 & 7.3 & 0.06 & 1.41 & 0.73 & 4.73 & 0.77 & 7.71 & 104.9 \\
\hline C0002K 7X-5 & 242 & 5.3 & 0.30 & 1.19 & 1.44 & 2.33 & 0.49 & 5.75 & 107.6 \\
\hline C0002K 9X-3 & 260 & 6.6 & 0.44 & 0.80 & 1.86 & 3.05 & 0.75 & 6.91 & 105.4 \\
\hline C0002L 3X-2 & 297 & 3.0 & 0.25 & 0.49 & 0.53 & 1.04 & 0.64 & 2.95 & 100.0 \\
\hline C0002L 6X-4 & 327 & 13.2 & 0.75 & 2.74 & 2.76 & 2.86 & 0.43 & 9.53 & 72.3 \\
\hline C0002L 8X-4 & 346 & 10.5 & 0.45 & 1.78 & 0.77 & 3.17 & 0.70 & 6.86 & 65.4 \\
\hline C0002L 9X-5 & 356 & 9.1 & 0.76 & 1.66 & 0.85 & 2.15 & 0.70 & 6.13 & 67.7 \\
\hline C0002L 11X-4 & 375 & 9.7 & 0.62 & 1.76 & 3.52 & 3.65 & 1.06 & 10.62 & 109.2 \\
\hline C0002L 12X-7 & 388 & 8.8 & 0.76 & 2.01 & 1.21 & 4.01 & 1.22 & 9.22 & 104.8 \\
\hline C0002L 13X-1 & 392 & 4.3 & 0.35 & 1.34 & 0.46 & 2.69 & 0.58 & 5.42 & 125.2 \\
\hline C0002L 16X-3 & 422 & 7.4 & 0.28 & 1.57 & 0.81 & 2.79 & 0.61 & 6.07 & 81.6 \\
\hline C0002L 17X-4 & 432 & 8.5 & 0.41 & 1.15 & 2.33 & 3.38 & 0.87 & 8.14 & 96.1 \\
\hline C0002L 19X-3 & 451 & 6.6 & 0.21 & 1.46 & 1.40 & 2.70 & 0.27 & 6.05 & 91.8 \\
\hline C0002L 24X-5 & 501 & 7.6 & 1.06 & 2.56 & 2.10 & 1.63 & 0.63 & 7.97 & 104.9 \\
\hline C0002B 16R-3 & 612 & 3.9 & 0.44 & 0.61 & 0.89 & 2.71 & 0.24 & 4.90 & 125.5 \\
\hline C0002B 27R-2 & 714 & 3.7 & 0.03 & 0.96 & 0.64 & 1.74 & 0.65 & 4.03 & 108.6 \\
\hline C0002L 37R-2 & 807 & 4.0 & 0.10 & 1.95 & 0.81 & 1.67 & 0.22 & 4.74 & 117.5 \\
\hline C0002B 38R-3 & 818 & 4.4 & 0.11 & 0.96 & 1.07 & 2.36 & 0.51 & 5.01 & 114.9 \\
\hline C0002B 59R-2 & 1011 & 6.5 & 0.07 & 0.35 & 0.69 & 7.35 & 1.03 & 9.48 & 146.7 \\
\hline
\end{tabular}

decreases linearly in Units I, III, and IV, whereas in Unit II, freshwater derived from the dissociation of methane hydrate diluted the IW, lowering the chlorinity of that unit. Here, we first discuss differences in the vertical variation of chemical components likely controlled by in situ microbial activity; later, we discuss sources of the IW.

In Unit $\mathrm{I}$, reduction of $\mathrm{SO}_{4}{ }^{2-}$ occurred just beneath the seafloor, leading to a low $\mathrm{SO}_{4}{ }^{2-}$ concentration there. The Fe concentration is also low in Unit I, probably owing to the precipitation of $\mathrm{FeS}_{2}$ (pyrite), because framboidal pyrite was observed throughout the sediment column (Strasser et al. 2014). $\mathrm{Br}^{-}, \mathrm{PO}_{4}{ }^{3-}$, and $\mathrm{NH}_{4}{ }^{+}$ increase with depth in Unit I; these results can be plausibly attributed to the decomposition of organic matter. Peak concentrations of these three components were observed in the uppermost part of Unit II; below that, their concentrations decreased with depth down to $400 \mathrm{mbsf}$.
The $\mathrm{SO}_{4}{ }^{2-}$ concentrations of Unit II are higher than those of the Unit I, in which $\mathrm{SO}_{4}{ }^{2-}$ reduction occurs just beneath the ocean bottom surface (Fig. 6). The similar decrease (3-6 mbsf) and increase (>400 mbsf) of $\mathrm{SO}_{4}{ }^{2-}$ concentrations were observed in the deep-sea sediments at IODP Sites 1173 and 1174 at Nankai Trough, about $100 \mathrm{~km} \mathrm{SW}$ from this study site. In those sediment columns, high $\mathrm{SO}_{4}{ }^{2-}$ was supplied from diffusive flux of sulfate from the oceanic basement into the overlaying sediments (e.g., Shipboard Scientific Party 2001a, b; Heuer et al. 2017). It would not be the case for the sediment column studied here, since the upward migration of deep fluid was limited (Toki et al. 2017). However, the $\mathrm{SO}_{4}{ }^{2-}$ would be derived diffusive flux of seawater and/or deep-sourced fluid (BG, described in the next paragraph).

We examined variations of IW chemistry in relation to the end-member composition of the IW (Fig. 7). Toki et al. 


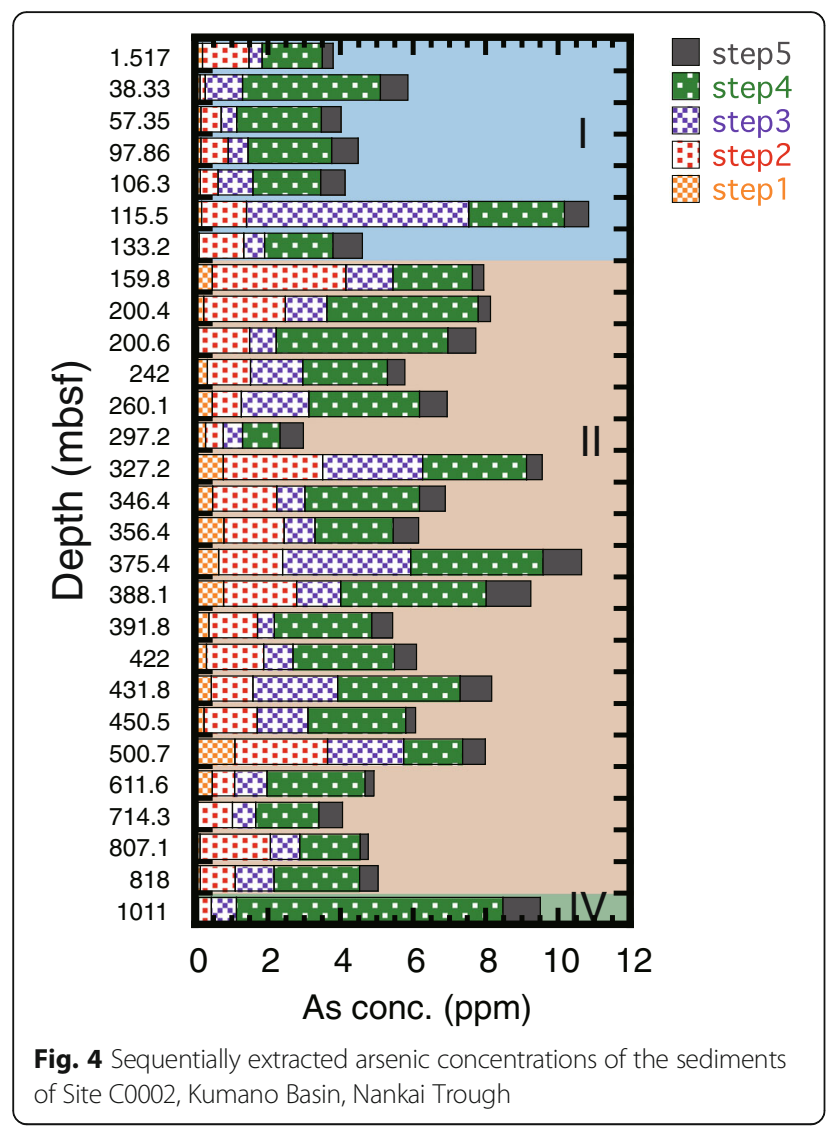

(2017) inferred that IW at Site C0002 is a mixture of three end members: SW (seawater); MH, freshwater derived from the dissociation of methane hydrate; and BG, defined as a deep-sourced fluid probably formed by ultrafiltration during burial diagenesis of IW in the old accretionary prism (Fig. 7a). SW, MH, and BG are characterized by chlorinity values of 550,140 , and $460 \mathrm{mM}$, respectively, and $\delta^{18} \mathrm{O}$ values of $0 \%$, $+1 \%$, and $-2.5 \%$, respectively. These three end members are typically found at the seafloor surface, around the methane hydrate concentration peak at about 400 mbsf, and below 1000 mbsf, respectively. Toki et al. (2017) suggested that the IW initially formed by the mixing of SW and BG via slow advection and was later modified by the addition of $\mathrm{MH}$ to the mixture. Most IW from Units I, III, and IV represents a mixture of SW and BG, whereas IW from Unit II is a mixture of $\mathrm{MH}$ with pre-existing SW-BG mixture. Concentrations of dissolved components associated with microbial activity and redox conditions are not just a simple function of the mixing ratios of the three end members. Figure 7 shows relationships among chemical components plausibly vary associated with As. Some components show contrasting distributions in four separate depth intervals: for example, $\mathrm{Br}^{-}$is enriched but the $\mathrm{Cl}^{-}$ concentration is unchanged from that of SW in Unit I, both $\mathrm{Cl}^{-}$and $\mathrm{Br}^{-}$are depleted in $\mathrm{MH}$, and $\mathrm{Cl}^{-}$is depleted with no change in the $\mathrm{Br}^{-}$concentration in BG
Table 3 Arsenic concentrations of soluble fractions extracted by hydroxylammonium chloride and phosphoric acid solution

\begin{tabular}{llllll}
\hline Sample name & $\begin{array}{l}\text { Depth } \\
\text { (mbsf) }\end{array}$ & \multicolumn{4}{l}{ Concentration } \\
\cline { 3 - 6 } & & $\begin{array}{l}\text { As(V) } \\
(\mathrm{ppm})\end{array}$ & $\begin{array}{l}\text { As(III)As(III) } \\
(\mathrm{ppm})\end{array}$ & $\begin{array}{l}\text { MAA } \\
(\mathrm{ppm})\end{array}$ & $\begin{array}{l}\text { AsB } \\
(\mathrm{ppm})\end{array}$ \\
\hline C0002K-1H-3 & 202 & 2.64 & 0.13 & 0.19 & 0.01 \\
C0002K-5 T-6 & 224 & 5.23 & 0.13 & 0.17 & 0.00 \\
C0002K-7X-5 & 242 & 3.20 & 0.57 & 0.00 & 0.00 \\
C0002K-10X-2 & 268 & 3.22 & 0.74 & 0.01 & 0.02 \\
C0002L-3X-2 & 297 & 2.87 & 0.10 & 0.02 & 0.01 \\
C0002L-5X-3 & 317 & 5.29 & 0.77 & 0.03 & 0.01 \\
C0002L-7X-2 & 335 & 3.37 & 0.14 & 0.09 & 0.00 \\
C0002L-9X-5 & 356 & 5.42 & 0.50 & 0.12 & 0.01 \\
C0002L-11X-4 & 375 & 7.07 & 1.22 & 0.11 & 0.01 \\
C0002L-13X-1 & 392 & 6.81 & 0.21 & 0.17 & 0.00 \\
C0002L-15X-4 & 412 & 3.73 & 0.14 & 0.08 & 0.01 \\
C0002L-17X-4 & 432 & 5.25 & 0.69 & 0.00 & 0.01 \\
C0002L-19X-3 & 451 & 6.49 & 0.27 & 0.06 & 0.01 \\
C0002L-21X-4 & 471 & 6.11 & 0.05 & 0.41 & 0.01 \\
C0022B-1H-2 & 1 & 2.56 & 0.32 & 0.00 & 0.01 \\
C0022B-2H-5 & 23 & 1.95 & 0.29 & 0.00 & 0.00 \\
C0022B-4H-2 & 39 & 0.66 & 0.07 & 0.01 & 0.01 \\
C0022B-8H-1 & 77 & 2.01 & 0.21 & 0.01 & 0.01 \\
C0022B-10T-2 & 90 & 4.56 & 0.11 & 0.09 & 0.00 \\
C0022B-13X-1 & 105 & 4.87 & 0.06 & 0.24 & 0.00 \\
C0022B-15X-3 & 118 & 6.26 & 0.09 & 0.09 & 0.00 \\
C0022B-19X-2 & 153 & 6.02 & 0.19 & 0.04 & 0.00 \\
C0022B-20X-4 & 194 & 3.01 & 0.41 & 0.07 & 0.00 \\
C0022B-21X-6 & 204 & 3.08 & 0.09 & 0.18 & 0.01 \\
C0022B-22X-1 & 210 & 5.91 & 0.21 & 0.00 & 0.01 \\
C0022B-24X-3 & 269 & 1.01 & 0.02 & 0.05 & 0.00 \\
C0022B-29X-2 & 301 & 3.00 & 0.14 & 0.04 & 0.00 \\
\hline
\end{tabular}

(in Units III and IV) (Fig. 7b). $\mathrm{Br}^{-}, \mathrm{PO}_{4}{ }^{3-}$, and $\mathrm{NH}_{4}{ }^{+}$ show weakly positive correlations in Unit I, whereas those components show strongly positive correlations in Unit II-1. IW from Units III and IV is characterized by low $\mathrm{PO}_{4}{ }^{3-}$ without changes in $\mathrm{Br}^{-}$and $\mathrm{NH}_{4}{ }^{+}$ concentrations (Fig. 7c, d). In Unit II-1, the Fe concentration seems to increase with the $\mathrm{PO}_{4}{ }^{3-}$ concentration (Fig. 7e). These features suggest that the IW geochemistry reflects the degree of biological degradation, and that microbial activity was most active in Unit II-1.

The $\mathrm{Br}^{-}$concentration (Fig. 6b), but not the $\mathrm{Cl}^{-}$concentration, of IW increased with depth in Unit I, probably because $\mathrm{Br}$ was released from sediments by the decomposition of $\mathrm{Br}$-containing organic matter derived from algae and marine animals, some of which 


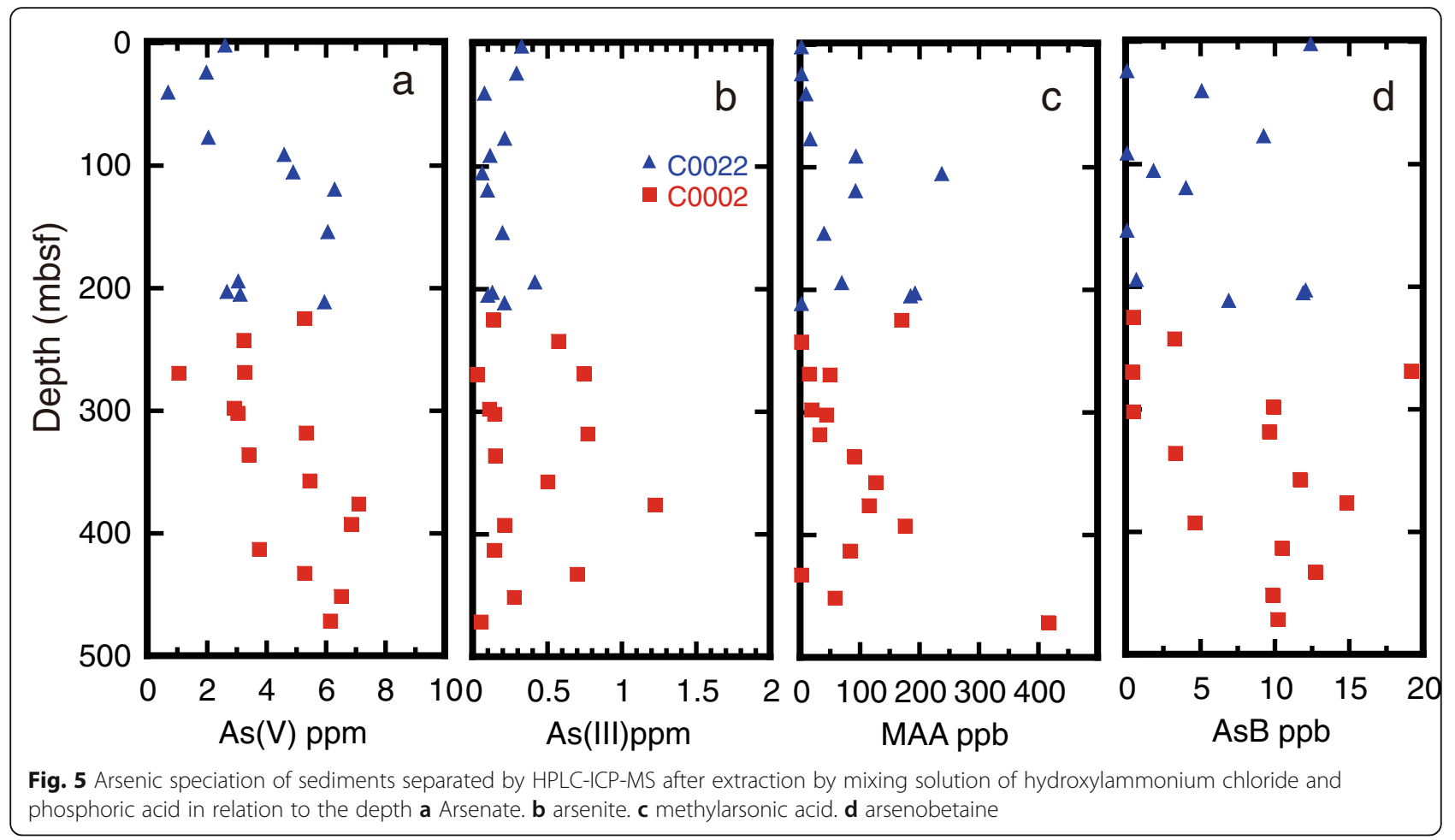

concentrate $\mathrm{Br}$ in various, mostly toxic, compounds such as bromoperoxidases (Hewson and Hager 1980), bromoform, and dobromoacetic acid (DBA) (e.g., Paul et al. 2006). Further, alkyl bromide compounds (Ma et al. 2010) have been extracted from algae, and 2,4-dibromophenol is produced by animal activity in coastal sediments (King 1988). Dehalogenation bacteria were recovered from the sediment column of Hole C0002 down to $150 \mathrm{mbsf}$, and Futagami et al. (2013) observed dehalogenation (bromide release) of 2,4,6-tribromophenol in an incubation experiment conducted with sediment from $4.7 \mathrm{mbsf}$. The freshwater derived from the dissociation of methane hydrate is not only low in $\mathrm{Cl}^{-}$but also in $\mathrm{Br}^{-}$(Fig. 7a). The BG end member is slightly depleted in $\mathrm{Cl}^{-}$but not in $\mathrm{Br}^{-}$ compared with SW. IW from Unit II was a mixture of $\mathrm{MH}, \mathrm{SW}$, and BG. The $\mathrm{Br}^{-}$concentration increased with increasing $\mathrm{PO}_{4}{ }^{3-}$ in Units I and II-1. High $\mathrm{Br}^{-}$and $\mathrm{PO}_{4}{ }^{3-}$ concentrations are probably attributable to the decomposition of algae, and the relationship between them showed different trends between Units I and II-1. Moreover, the

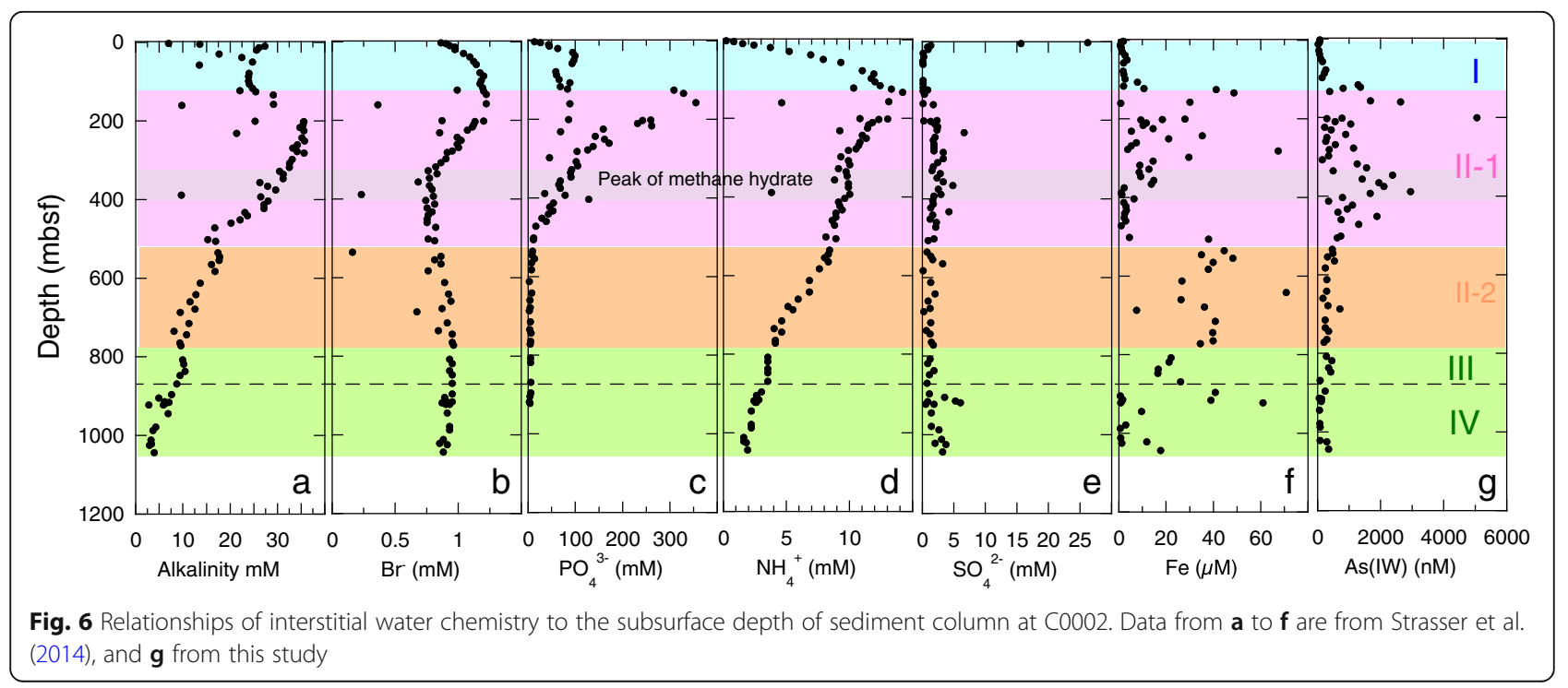





Fig. 7 Relationships of total $\mathrm{As}$ and $\delta^{18} \mathrm{O}$ and dissolved chemical components in IW sensitive to changing redox condition a: chlorinity and $\delta^{18} \mathrm{O}$; b: chrolinity and $\mathrm{Br}$ concentration; $\mathbf{c}: \mathrm{Br}^{-}$and $\mathrm{PO}_{4}{ }^{3-}$ concentrations; d: $\mathrm{NH}_{4}{ }^{+}$and $\mathrm{PO}_{4}{ }^{3-}$ e: $\mathrm{PO}_{4}{ }^{3-}$ and $\mathrm{Fe} ; \mathbf{f}: \mathrm{PO}_{4}{ }^{3-}$ and $\mathrm{As} ; \mathbf{g}: \mathrm{pH}$ and $\mathrm{As} ; \mathrm{Fe}$ and $\mathrm{As}$. SW, $\mathrm{MH}$, and $\mathrm{BG}$ are the seawater, dissolved water from methane hydrate, and diagenetically altered interstitial water, respectively (a referred Toki et al. (2017) was modified). Data except As concentrations were from Moore et al. (2013) and Toki et al. (2017)

relationship between $\mathrm{NH}_{4}{ }^{+}$and $\mathrm{PO}_{4}{ }^{3-}$ in IW showed different trends even more clearly between Units I and II-1. These differences between Units I and II-1 suggest that the sources of $\mathrm{Br}^{-}, \mathrm{PO}_{4}{ }^{3-}$, and $\mathrm{NH}_{4}{ }^{+}$differed between these Units (Fig. 7c, d). IW was depleted $\mathrm{PO}_{4}{ }^{3-}$ in Unit III and IV, and the relationship to $\mathrm{Br}^{-}$and $\mathrm{NH}_{4}{ }^{+}$can be explained by the mixing of $\mathrm{BG}$ and $\mathrm{MH}$.

The high bulk As concentrations in both sediment and IW in Unit II-1 (Fig. 2), along with the high $\mathrm{Br}^{-}, \mathrm{PO}_{4}{ }^{3-}$, and $\mathrm{NH}_{4}{ }^{+}$concentrations of IW, imply that these components had similar sources, i.e., marine biology especially such as algae. In Unit II-1, the As concentration increased with increasing $\mathrm{pH}$ (Fig. $7 \mathrm{~g}$ ) but not in relation to either $\mathrm{PO}_{4}{ }^{3-}$ or Fe (Fig. 7f, h). From the combined results of sequential extraction and leaching analyses, we can infer that a considerable amount of $\mathrm{As}^{\mathrm{V}}$ was associated with Fe-oxyhydroxides and that the As concentration of IW was largely controlled by the $\mathrm{pH}$. The adsorption-desorption affinity of As onto Fe-oxyhydroxides is mainly controlled by the solution $\mathrm{pH}$; adsorption of arsenate $\left(\mathrm{As}^{\mathrm{V}}\right)$ occurs at $\mathrm{pH} 5-6$, whereas desorption becomes dominant at higher pH (e.g., Pearce and Moore 1982; Bowell et al. 1994; Dixit and Hering 2003).

MMA, one of the simplest organoarsenicals, is derived from the decomposition of arsenosugars contained in phytoplankton and algae (Edmonds et al. 1997; Morita and Shibata 1990). AsB (arsenobetaine), the simplest protein containing As, is derived from marine animals (e.g., Francesconi and Edmonds 1996). Decomposition rates of organic As in sediments are high: Takeuchi et al. (2005) observed that in surface sediments from a coastal area, which were plausibly more oxic than the deep-sea sediments studied here, organic As was largely decomposed within approximately 60 years. The ages of the sediments from 200 to $500 \mathrm{mbsf}$ in Hole C0002K and C0002L, corresponding to Unit II-1 in this study, were constrained from 1.04 to 1.34 Ma by biostratigraphy and magnetostratigraphy conducted during Expedition 315 (Strasser et al. 2014; Expedition 315 Scientists 2009). MMA can form in situ by microbial methylation (Reimer and Thompson 1988) in conjunction with methane formation. Sulfate-reducing and nitrogen-fixing bacteria were detected with methanogen, which mostly uses $\mathrm{CO}_{2}$ and $\mathrm{H}_{2}$ for producing $\mathrm{CH}_{4}$, from the sediments down to 193.29 mbsf at IODP Site 1173, located in the Nankai Trough and about $100 \mathrm{~km} \mathrm{SW}$ of our study site (Newberry et al. 2004). In the same sediment column down to 194 mbsf, epsilon-proteobacterial clones, of which species used a diverse spectrum of electron accepters, such as $\mathrm{O}_{2}$ in low concentrations, $\mathrm{NO}_{3}{ }^{-}, \mathrm{S}^{\circ}$, and $\mathrm{S}_{2} \mathrm{O}_{3}{ }^{2-}$, were also detected, and it was notable that these clones could also respire with $\mathrm{Fe}(\mathrm{III})$ and arsenate (Kormas et al. 2003). The similar microbial assemblage would be expected in the Unit II-1 of our studied column, of which IW contained $\mathrm{SO}_{4}{ }^{2-}$. AsB, an organic As compound that is synthesized and degraded in biotransformation cycles, is ubiquitous in marine, terrestrial, and deep-sea hydrothermal systems (Hoffmann et al. 2018). In light of the results reported by Hoffmann et al. (2018), we can infer that the AsB in the deep-sea sediments studied here was also a product of in situ microbial activity. Thus, the detection of organic As compounds suggests that considerable amounts of 
mobile As in the studied sediment column may have been derived in relation to microbial activity via both degradation and synthesis of organic As compounds in the sediment column.

\section{Conclusions}

Arsenic is actively released into IW at depths of methane hydrate layer of deep-sea sediments of the Nankai Trough, offshore Japan. The release of As accompanies the degradation of organic matter and following change of redox condition to control the adsorption/desorption affinity of As onto the Fe-oxyhydroxides. The sources of the As in the sediment column are not clear at present. However, a considerable amount of mobile As must be derived from marine organisms. It is notable that As mobilization in deep-sea sediments is associated with microbial activity in deep-sea sediments where methane hydrate appears.

\section{Acknowledgements}

The authors sampled the studied sediments and IW in collaboration with the crews and onboard scientists of Expeditions 338 and 348. The stored samples taken during Expedition 315 were provided by the Kochi Core Center, which is directed by Dr. Lalan Gupta. T. Shimonaka and K. Okazaki supported for conducting shore-based laboratory analyses. The comments from Dr. T. Kakegawa and two anonymous reviewers were helpful to improve the manuscript. We thank to all of them. This study was financially supported by post-cruise IODP studies to HM, SF and EE, and KAKENHI (No. 17K18810).

\section{Funding}

Samples were collected on Drilling Vessel "Chikyu" under IODP program during Expeditions 338 and 348.

Post cruise research fund from JAMSTEC for HM, SF and EE and KAKENHI (No. 17K18810) were used for As analyses.

\section{Availability of data and materials}

All data newly obtained from this study is in the manuscript and data sharing is not applicable.

\section{Authors' contributions \\ HM carried out the sample collection and pretreatments on Exp. 338, helped in the analysis of water-soluble As, wrote the manuscript, and drew the figures. $\mathrm{HY}$ helped in the analyses of As of interstitial water and sediments. SF helped in the sample collection and pretreatments on Exp. 348, analysis of water- soluble As with HY, and discussion. TT helped in the sample collection and pretreatments on Exp. 338, and discussion. EE contributed to the sample collection and pretreatments on Exp. 348. All authors read and approved the final manuscript.}

\section{Competing interests}

The authors declare that they have no competing interests.

\section{Publisher's Note}

Springer Nature remains neutral with regard to jurisdictional claims in published maps and institutional affiliations.

\section{Author details}

${ }^{1}$ Department of Biology and Geosciences, Graduate School of Science, Osaka City University, 3-3-138 Sugimoto, Sumiyoshi-ku, Osaka 558-8585, Japan. ${ }^{2}$ Present Address: Marine Environment Section, Center for Regional Environmental Research, National Institute for Environmental Studies, 16-2 Onogawa, Tsukuba, Ibaraki 305-8506, Japan. ${ }^{3}$ Department of Chemistry, Biology and Marine Science, Faculty of Science, University of the Ryukyus, 1 Senbaru, Nishihara, Okinawa 903-0123, Japan.
Received: 30 April 2018 Accepted: 27 January 2019

Published online: 21 March 2019

\section{References}

AIST (2018) Geochemical map of sea and land of Japan. https://gbank.gsj.jp/ geochemmap/ocean/data/ganyuryo/ocean-noudo.csv. (18 Apr 2018)

Andreae MO (1979) Arsenic speciation in seawater and interstitial waters: the influence of biological-chemical interactions on the chemistry of a trace element. Limnol Ocean 24:440-452

Ashi J, Lallemant S, Masago H, the Expedition 315 Scientists (2008) NanTroSEIZE stage 1A: NanTroSEIZE megasplay riser pilot. IODP Prel Rept 315. https://doi. org/10.2204/iodp.pr.315.2008

Bowell RJ, Morley NH, Din VK (1994) Arsenic speciation in porewaters, Ashanti mine, Ghana. Appl Geochem 9:9-14

Dixit S, Hering JG (2003) Comparison of arsenic(V) and arsenic(III) sorption onto Iron oxide minerals: implications for arsenic mobility. Environ Sci Technol 37: 4182-4189. https://doi.org/10.1021/es030309t

Duncan EG, Haher WA, Foster SD (2015) Contribution of arsenic species in unicellular algae to the cycling of arsenic in marine environment. Environ Sci Technol 49:33-50

Edmonds JS, Francesconi KA, Cannon JR, Raston CL, Skelton BW, White AH (1977) Isolation, crystal structure and synthesis of arsenobetaine, the essential constituent of the western rock lobster Panulirus longipes cygnus George. Tetrahedron Lett 18:1543-1546

Edmonds JS, Francesconi KA, Rippingale RJ, Morita M (1997) Arsenic transformations in short marine food chains studied by HPLC-ICP MS. App Organometal Chem 11:281-287

Ellwood MJ, Maher WA (2003) Measurement of arsenic species in marine sediments by high-performance liquid chromatography-inductively coupled plasma mass spectrometry. Anal Chim Acta 477:279-291

Expedition 315 Scientists (2009) Expedition 315 site C0001. In: Kinoshita M, Tobin H, Ashi J, Kimura G, Lallemant S, Screaton EJ, Curewitz D, Masago H, Moe KT, the Expedition 314/315/316 Scientists (eds) Proc. IODP, 314/315/316. Integrated Ocean Drilling Program Management International, Inc, Washington, DC. https://doi.org/10.2204/iodp.proc.314315316.123.2009

Expedition 348 Scientists and Scientific Participants (2014) NanTroSEIZE stage 3: NanTroSEIZE plate boundary deep riser 3. IODP Prel Rept 348. https://doi.org/ 10.2204/iodp.pr.348.2014

Francesconi KA, Edmonds JS (1996) Arsenic and marine organisms. Adv Inorg Chem 44:147-189

Futagami T, Morono Y, Terada T, Kaksonen AH, Inagaki F (2013) Distribution of dehalogenation activity in subseafloor sediments of the Nankai Trough subduction zone. Phil Trans Royal Soc B 368. https://doi.org/10.1098/rstb.2012.0249

Handley KM, Lloyd JR (2013) Biogeochemical. implications of the ubiquitous colonization of marine habitats and redox gradients by Marinobacter species. Front Microbiol 4:1-10.

Heuer VB, Inagaki F, Morono Y, Kubo Y, Maeda L, Expedition 370 Scientists (2017) Expedition 370 preliminary report: temperature limit of the deep biosphere off Muroto. International Ocean Discovery Program. https://doi.org/10.14379/ iodp.pr.370.2017

Hewson WC, Hager LP (1980) Bromoperoxidases and halogenated lipids in marine algae 1. J Phycol. https://doi.org/10.1111/j.1529-8817.1980.tb03043.x

Hoffmann T, Warmbold B, Smits SHJ, Tschapek B, Ronzheimer S, Bashir A, Chen C, Rolbetzki A, Pittelkow M, Jebbar M, Seubert A, Schmitt L, Bremer E (2018) Arsenobetaine: an ecophysiologically important organoarsenical confers cytoprotection against osmotic stress and growth temperature extremes. Environ Microbiol 20:305-323

King GM (1988) Dehalogenation in marine sediments containing natural sources of halophenols. Appl Environ Microbiol 54:3079-3085

Kormas KA, Smith DC, Edgcomb V, Teske A (2003) Molecular analysis of deep subsurface microbial communities in Nankai Trough sediments (ODP leg 190, site 1176). FEMS Microbiol Ecol 45:115-125

Ma JM, Cai LL, Zhang BJ, Hu LW, Li XY, Wang JJ (2010) Acute toxicity and effects of 1-alkyl-3-methylimidazolium bromide ionic liquids on green algae. Ecotoxicol Environ Safety 73:1465-1469

Manheim FT (1966) A hydraulic squeezer for obtaining interstitial waters from consolidated and unconsolidated sediments. Geol Surv Prof Pap (U.S.) 550-C: 256-261

Masuda H (2018) Arsenic cycling in the Earth's crust and hydrosphere: interaction between naturally occurring arsenic and human activities. Prog Earth Planet Sci 5:68. https://doi.org/10.1186/s40645-018-0224-3 
Moore G, Kanagawa K, Strasser M, Dugan B, Maeda L, Toczko S, the Expedition 338 Scientists (2013) NanTroSEIZE stage 3: NanTroSElZE plate boundary deep riser 2. In: IODP Prelim Rep. Integrated Ocean Drilling Program Management International, Inc

Moore GF, Park JO, Bangs NL, Gulick SP, Tobin HJ, Nakamura Y, Saito S, Tsuji T, Yoro T, Tanaka H, Uraki S, Kido Y, Sanada Y, Kuramoto S, Taira A. (2009) Structural and seismic stratigraphic framework of the NanTro-SEIZE State 1 transect: Kumano 3D seismic survey. In: Kinoshita, M., Tobin, H., Ashi, J., Kimura, G., Lallement, S., Screaton, E.J., Curewitz, D., Masago, H., Moe, K.T., Scientists, E. (Eds.), Proceedings of the Integrated Ocean Drilling Program. Integrated Ocean Drilling Program Management International, Inc, 46

Morita M, Shibata Y (1990) Chemical form of arsenic in marine macroalgae. Appl Organomet Chem 4:181-190

Neff JM (2002) Chapter 3 - Arsenic in the ocean, Bioaccumulation in Marine Organisms. Elsevier, Oxford, pp. 57-78.

Newberry CJ, Webster G, Cragg BA, Parkes RJ, Weightman AJ, Fry JC (2004) Diversity of prokaryotes and methanogenesis in deep subsurface sediments from the Nankai Trough, Ocean Drilling Program leg 190. Environ Microbiol 6:274-287

Paul NA, de Nys R, Steinberg PC (2006) Chemical defence against bacteria in the red alga Asparagopsis armata: linking structure with function. Mar Ecol Prog Ser 306:87-101

Pearce ML, Moore CB (1982) Adsorption of arsenite and arsenate on amorphous iron hydroxides. Water Res 16:1247-1253

Raab A, Fecher P, Feldmann J (2005) Determination of arsenic in algae-results of an interlaboratory trial: determination of arsenic species in the watersoluble fraction. Microchim Acta 151:153-166

Rauret G, López-Sánchez JF, Sahuquillo A, Rubio R, Davidson C, Ure A, Quevauviller P (1999) Improvement of the BCR three step sequential extraction procedure prior to the certification of new sediment and soil reference materials. J Environ Monit 1:57-61

Reimer K, Thompson JA (1988) Arsenic speciation in marine interstitial water. The occurrence of organoarsenicals. Biogeochem 6:211-237

Sanders JG (1979) The concentration and speciation of arsenic in marine macroalgae. Estuar Coast Mar Sci 9:95-99

Shipboard Scientific Party (2001a) Site 1173. In: Moore GF, Taira A, Klaus A et al (eds) Proceedings of the Ocean Drilling Program, Initial Reports, 190. Ocean Drilling Program, College Station, pp 1-147. https://doi.org/10.2973/odp.proc ir.190.104.2001

Shipboard Scientific Party (2001b) Site 1174. In: Moore GF, Taira A, Klaus A et al (eds) Proceedings of the Ocean Drilling Program, Initial Reports, 190. Ocean Drilling Program, College Station, pp 1-149. https://doi.org/10.2973/odp.proc. ir.190.105.2001

Strasser M, Dugan B, Kanagawa K, Moore GF, Toczko S, Maeda L, the Expedition 338 Scientists (2014) Proc. IODP, 338. Integrated Ocean Drilling Program, Yokohama. https://doi.org/10.2204/iodp.proc.338.2014

Takeuchi M, Terada A, Nanba K, Kanai Y, Owaki M, Yoshida T, Kuroiwa T, Nirei H, Komai T (2005) Distribution and fate of biologically formed organoarsenicals in coastal marine sediment. Appl Organometal Chem 19:945-951

Toki T, Kinoshita M, Morita S, Masuda H, Rashid H, Yoshinishi H, Nakano T, Noguchi T (2017) The vertical chloride ion profile at the IODP site C0002, Kumano Basin, off coast of Japan. Tectonophysics 710-711:88-96

\section{Submit your manuscript to a SpringerOpen ${ }^{\circ}$ journal and benefit from:}

- Convenient online submission

- Rigorous peer review

- Open access: articles freely available online

- High visibility within the field

- Retaining the copyright to your article

Submit your next manuscript at $\boldsymbol{\nabla}$ springeropen.com 